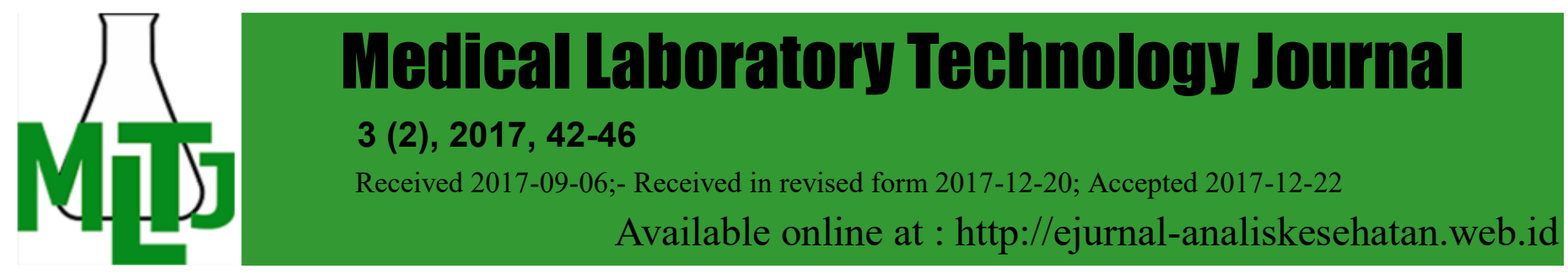

\title{
ANEMIA DAN LAMA KONSUMSI OBAT ANTI TUBERCULOSIS
}

\author{
Anny Thuraidah, Rima Agnes Widya Astuti, Dinna Rakhmina
}

\author{
Jurusan Analis Kesehatan Poltekkes Kemenkes Banjarmasin \\ JI Mistar Cokrokusumo 4a Banjarbaru \\ e-mail: thuraidahapt@gmail.com
}

\begin{abstract}
Tuberculosis is an infectious disease due to Mycobacterium tuberculosis germ that can infect several organs, including the lungs, kidneys, and bones. The goal of treatment of tuberculosis is tuberculosis bacilli destroy quickly and prevent recurrence. First category treatment of tuberculosis is isoniazid, rifampin, streptomycin, ethambutol, and pyrazinamide. Although the most anti-tuberculosis drug is acceptable in therapy, but have potentially toxic effects hematologic reactions such as agranulocytosis, eosinophilia, thrombocytopenia, and anemia. This research aims to know the correlation between anti-tuberculosis drug consumption in pulmonary TB patients against anemia. Method of this research was Analytical Survey with a Cross-Sectional design. The average results of red blood cell count for 0 months 5,16 106/uL, 2 months 4,39 106/uL and 6 months 4,61 106/uL, haemoglobin levels for 0 month 15,17 g/dL, 2 months $12,73 \mathrm{~g} / \mathrm{dL}$ and 6 months $13,28 \mathrm{~g} / \mathrm{dL}$ as well as hematocrit value for 0 month 44,26 \%, 2 months 38,24 \% and 6 months 39,04\%. From Spearman statistics analytical was obtained significant of red blood cell count $0.004<\alpha(0.05)$, levels of hemoglobin $0.007<\alpha(0.05)$ and the value of hematocrit $0.015<\alpha(0.05)$, it was concluded there was correlation between long consumption of anti-tuberculosis drug with anemia and the value of the correlation coefficient count of red blood cells -0.531 , levels of hemoglobin- 0.479 as well as the value of hematocrit 0.440 means has the power correlations are medium. Further research is recommended to use different parameters such as the number of platelets, AST/ALT levels and should use the same patient sample or from 0 months up to 6 months
\end{abstract}

Keywords: anti-tuberculosis drug; pulmonary tuberculosis; anemia

Abstrak: Tuberkulosis adalah penyakit infeksi akibat kuman Mycobacterium tuberculosis yang dapat menginfeksi beberapa organ tubuh, diantaranya paru-paru, ginjal, dan tulang.Tujuan pengobatan tuberkulosis adalah memusnahkan basil tuberkulosis dengan cepat dan mencegah kekambuhan. Obat anti tuberkulosis (OAT) dapat diterima dalam terapi, namun mempunyai efek toksik seperti agranulositosis, eosinofilia, trombositopenia dan anemia. Penelitian ini bertujuan untuk mengetahui hubungan lama konsumsi OAT pada pasien TB paru terhadap anemia. Penelitian ini bersifat Survey Analitic dengan rancangan Cross Sectional. Hasil penelitian rata-rata hitung sel darah merah 0 bulan $5,1610^{6} / \mathrm{uL}, 2$ bulan 4,39 10\% $\mathrm{uL}$ dan 6 bulan 4,61 10\% $\mathrm{uL}$, rata-rata kadar hemoglobin 0 bulan 15,17 g/dL, 2 bulan 12,73 g/dL dan 6 bulan 13,28 g/dL serta ratarata nilai hematokrit 0 bulan 44,26 \%, 2 bulan 38,24\% dan 6 bulan 39,04\%. Dari hasil uji Spearman diperoleh nilai signifikan sebesar hitung sel darah merah $0,004<\alpha(0,05)$, kadar hemoglobin $0,007<\alpha(0,05)$ dan nilai hematokrit $0,015<\alpha(0,05)$ sehingga dapat disimpulkan ada hubungan antara lama konsumsi obat anti tuberkulosis pada pasien TB paru terhadap anemia dan nilai correlation coefficient hitung sel darah merah $-0,531$, kadar hemoglobin $-0,479$ serta nilai hematokrit $-0,440$ berarti memiliki kekuatan hubungan yang sedang. Disarankan untuk penelitian selanjutnya menggunakan parameter yang berbeda seperti jumlah trombosit, kadar AST/ALT dan sebaiknya menggunakan sampel atau pasien yang sama dari 0 bulan sampai 6 bulan.

Kata kunci: obat anti tuberculosis; tuberculosis paru; anemia 


\section{PENDAHULUAN}

Tuberkulosis adalah penyakit infeksi akibat kuman Mycobacterium tuberculosis yang dapat menginfeksi beberapa organ tubuh, diantaranya paruparu, ginjal, dan tulang (Istiantoro $\mathrm{YH}$ \& Setiabudy R, 2012). Laporan WHO tahun 2014 di dunia terdapat 9,6 juta orang terinfeksi tuberkulosis dan 1,5 juta orang meninggal kerena penyakit tersebut. Sampai saat ini penyakit tuberkulosis masih menjadi masalah kesehatan yang utama, baik di dunia maupun di Indonesia. Negara Indonesia merupakan kontributor penderita TB paru terbesar ketiga setelah India dan Cina. Penyakit ini juga merupakan penyebab kematian urutan ketiga setelah penyakit jantung dan penyakit saluran pernapasan (Crofton J dkk., 2002). Menurut profil kesehatan Indonesia tahun 2015 terjadi peningkatan kasus TB paru dari tahun sebelumnya yaitu 324.539 kasus menjadi 330.910 kasus di wilayah Indonesia. Menurut Ditjen Pencegahan dan Pengendalian Penyakit Kemenkes RI tahun 2016 Kalimantan Selatan menempati posisi ke-14 yaitu sebesar 128 per 100.000 penduduk menderita TB paru.Menurut profil kesehatan provinsi Kalimantan Selatan tahun 2012 Banjarbaru menduduki posisi ke-6 teratas untuk kasus TB baru BTA positif yang ditemukan. Menurut data dari Dinas Kesehatan Kota Banjarbaru tahun 2015 masih banyak masyarakat Banjarbaru yang terinfeksi penyakit TB paru, hal ini terbukti dari Puskesmas Guntung Payung yang mempunyai 79 kasus BTA positif.

Penyakit ini dapat menyebabkan tubuh menjadi lelah, lemas, penurunan berat badan, demam, batuk kronis, dan dalam sputum terdapat bercak darah. Tujuan pengobatan tuberkulosis adalah memusnahkan basil tuberkulosis dengan cepat dan mencegah kekambuhan.Pengobatan tuberkulosis harus selalu mengikuti dua tahapan yaitu tahap intensif dan tahap lanjutan. Pada tahap intensif pengobatan diberikan setiap hari selama 2 bulan dimaksudkan agar secara efektif menurunkan jumlah kuman yang ada dalam tubuh pasien. Pada tahap lanjutan pasien diberikan jenis obat yang lebih sedikit, namun dalam jangka waktu yang lebih lama yaitu 4 bulan, tahap lanjutan sangat penting untuk mencegah terjadinya kekambuhan (Istiantoro $\mathrm{YH}$ \& Setiabudy R, 2012; Subuh M, 2014).

Pengobatan tuberkulosis dengan obat anti tuberkulosis (OAT) utama yaitu meliputi isoniazid, rifampisin, etambutanol, streptomisin, dan pirazinamid (Istiantoro YH \& Setiabudy $R, 2012$ ). Isoniazid atau yang sering disingkat INH dapat menyebabkan demam, reaksi hematologik seperti anemia, agranulositosis, eosinofilia dan trombositopenia.Rifampisin juga mempunyai efek samping terhadap reaksi hematologik seperti anemia dan trombositopenia. Walaupun sebagian besar obat anti tuberkulosis (OAT) dapat diterima dalam terapi, namun mempunyai efek toksik yang potensial diantaranya terhadap efek samping reaksi hematologik seperti anemia, agranulositosis, eosinofilia dan trombositopenia (Istiantoro YH \& Setiabudy $R, 2012$ ).

Anemia adalah keadaan dimana rendahnya jumlah sel darah merah, kadar hemoglobin, dan hitung sel darah merah, kadar hemoglobin dan nilai hematokrit. Anemia dapat disebabkan karena kehilangan darah, kekurangan produksi sel darah merah dan penghancuran sel darah merah. Anemia yang disebabkan karena penghancuran sel darah merah disebut juga anemia hemolitik. Anemia hemolitik dibagi menjadi dua golongan yaitu anemia hemolitik karena faktor di dalam sel darah merah sendiri dan anemia hemolitik karena faktor di luar sel darah merah. Anemia hemolitik karena faktor di luar sel darah merah salah satunya adalah karena obat-obatan. Isoniazid dan rifampisin adalah obat yang dapat menyebabkan anemia hemolitik dengan mekanisme kompleks imun, kompleks obat antibodi mengikat memban sel darah merah dan memicu aktivasi komplemen sehingga menimbulkan hemolisis sel darah merah atau penghancuran sel darah merah (Bakta IM, 2006). Parameter pemeriksaan anemia yaitu meliputi hitung sel darah merah, kadar hemoglobin dan nilai hematokrit (Bakta IM, 2006).

Menurut Automatic hematology analyzer XS -500i Nilai normal hitung sel darah merah pada laki-laki adalah sebesar 4,5-5,9 $10^{6} / \mathrm{LL}$ sedangkan pada perempuan sebesar $4,5-5,110^{6} / \mathrm{uL}$, nilai normal kadar hemoglobin pada lakilaki adalah sebesar 14,0-17,4 g/dL sedangkan pada perempuan sebesar 12,315,3 g/dL dan nilai normal hematokrit pada laki-laki adalah sebesar $42,050,0 \%$ sedangkan pada perempuan sebesar 36,0 $45,0 \%$. 
Penelitian ini bertujuan untuk mengetahui hubungan lama konsumsi obat anti tuberkulosis pada pasien TB Paru terhadap anemia.

\section{BAHAN DAN METODE}

Jenis penelitian ini adalah Survey Analitic yaitu penelitian yang dilakukan tanpa melakukan intervensi terhadap subjek penelitian. Penelitian ini dilakukan untuk mengetahui apakah ada hubungan antara lama konsumsi obat anti tuberkulosis pada pasien TB paru terhadap anemia Rancangan penelitian yang di gunakan adalah Cross Sectional, yaitu pengukuran variabel independent pada saat yang sama.

Populasi penelitian ini adalah pasien TB paru di Puskesmas Guntung Payung dan Puskesmas Landasan Ulin. Sampel penelitian adalah pasien TB paru kategori I yang belum mengkonsumsi OAT (0 bulan), pasien TB paru yang sudah mengkonsumsi OAT selama 2 bulan dan 6 bulan.Teknik pengambilan sampel yang digunakan adalah accidental sampling dengan kriteria responden tidak merokok, tidak mengkonsumsi alcohol, pola hidup sehat.

Pengumpulan data penelitian didahului dengan permintaan kesediaan sebagai responden melalui Informed Consent dan dilakukan wawancara berisi pertanyaanpertanyaan tentang keseharian responden sebagai data pendukung. Pengambilan sampel darah vena dan pemeriksaan hitung sel darah merah, kadar hemoglobin dan nilai hematokrit menggunakan Hematology Analyzer Sysmex XS-500i.

\section{HASIL DAN PEMBAHASAN}

Berikut hasil pengukuran hitung sel darah merah, kadar hemoglobin dan nilai hematokrit sesuai dengan lama konsumsi obat anti tuberkulosis:

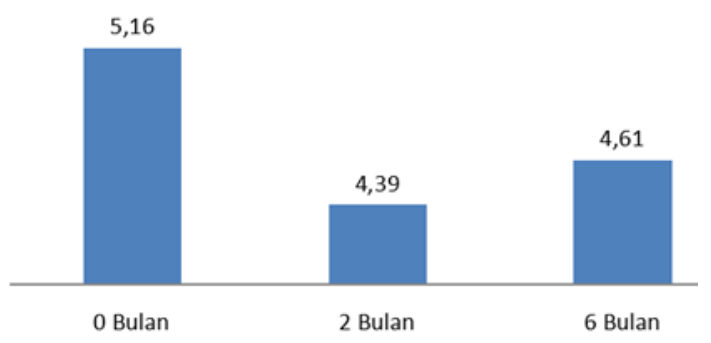

Gambar 1. Grafik Hasil Rata-Rata Sel Darah Merah $\left(10^{6} / \mathrm{uL}\right)$ dengan Lama Konsumsi Obat Anti Tuberculosis

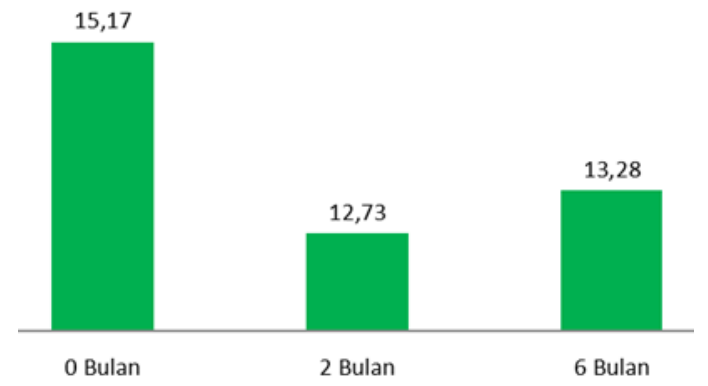

Gambar 2. Grafik Hasil Rata-Rata Hemoglobin (g/dL) dengan Lama Konsumsi Obat Anti Tuberculosis

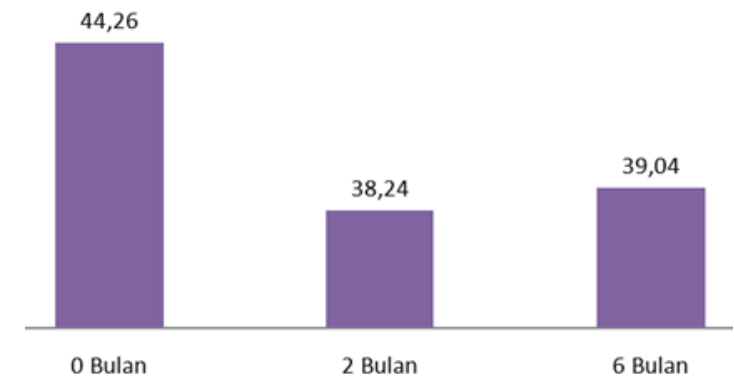

Gambar 3. Grafik Hasil Rata-Rata Hematokrit (\%) dengan Lama Konsumsi Obat Anti Tuberculosis

Tabel 1. Hasil hitung sel darah merah, kadar hemoglobin dan nilai hematokrit dengan lama konsumsi obat anti tuberculosis

\begin{tabular}{|c|c|c|c|}
\hline \multirow{2}{*}{$\begin{array}{l}\text { Hasil rata-rata } \\
\text { pemeriksaan }\end{array}$} & \multicolumn{3}{|c|}{ Lama Konsumsi OAT (bulan) } \\
\hline & 0 & 2 & 6 \\
\hline $\begin{array}{l}\text { Hitung Sel Darah } \\
\text { Merah (106/uL) }\end{array}$ & 5,16 & 4,37 & 4,61 \\
\hline $\begin{array}{l}\text { Kadar Hemoglobin } \\
(\mathrm{g} / \mathrm{dL})\end{array}$ & 15,17 & 12,73 & 13,28 \\
\hline $\begin{array}{l}\text { Nilai Hematokrit } \\
(\%)\end{array}$ & 44,26 & 38,24 & 39,04 \\
\hline
\end{tabular}

Untuk mengetahui hubungan lama konsumsi obat anti tuberkulosis pada pasien TB paru terhadap anemia dilakukan uji spearman karena data tersebut tidak berdistribusi normal. Hasil penelitian ini didapatkan nilai signifikan (2-tailed) hitung sel darah merah 0,004 < $\alpha(0,05)$, kadar hemoglobin $0,007<\alpha(0,05)$ dan nilai hematokrit $0,015<\alpha(0,05)$ maka Ho ditolak, ini berarti ada hubungan antara lama konsumsi obat anti tuberkulosis pada pasien TB paru terhadap anemia. 
Untuk mengetahui korelasi kekuatan suatu hubungan bisa dilihat pada nilai correlation coefficient hitung sel darah merah yaitu 0,531 , kadar hemoglobin $-0,479$ dan nilai hematokrit $-0,440$ yang berarti hubungan antara lama konsumsi obat anti tuberkulosis pada pasien TB paru terhadap anemia memiliki kekuatan hubungan yang sedang. Semakin lama mengonsumsi obat maka semakin turun nilai hitung sel darah merah, haemoglobin dan hematokrit.

Berdasarkan hasil pemeriksaan yang telah dilakukan pada pasien TB paru yang belum mengkonsumsi OAT (0 bulan) dan yang sudah mengkonsumsi OAT selama 2 bulan dan 6 bulan, didapatkan hasil rata-rata hitung sel darah merah 0 bulan $5,1610^{6} / \mathrm{uL}, 2$ bulan $4,3910^{6} / \mathrm{uL}$ dan 6 bulan 4,61 10\% $\mathrm{uL}$. Hasil rata-rata kadar hemoglobin 0 bulan $15,17 \mathrm{~g} / \mathrm{dL}$, 2 bulan $12,73 \mathrm{~g} / \mathrm{dL}$ dan 6 bulan $13,28 \mathrm{~g} / \mathrm{dL}$ serta hasil rata-rata nilai hematokrit 0 bulan $44,26 \%, 2$ bulan 38,24\% dan 6 bulan 39,04 $\%$.

Pengobatan tuberkulosis dengan obat anti tuberkulosis (OAT) utama yaitu meliputi isoniazid, rifampisin, etambutol, streptomisin, dan pirazinamid (Istiantoro $\mathrm{YH}$ \& Setiabudy $\mathrm{R}$, 2012).Masing-masing obat anti tuberkulosis tersebut mempunyai efek samping yang menyebabkan terjadinya efek toksik terhadap tubuh.Obat anti tuberkulosis yang mempunyai efek toksik terhadap darah diantaranya isoniazid yang menyebabkan anemia, agranulositosis, eosinofilia dan trombositopenia.Rifampisin menyebabkan trombositopenia dan anemia, streptomisin menyebabkan agranulositosis. Sedangkan etambutol dan pirazinamid tidak memiliki efek toksik terhadap darah (Istiantoro YH \& Setiabudy R, 2012). Efek-efek toksik tersebut akan saling bersinergi dalam menyebabkan kelainan pada darah dalam hal ini yaitu terjadinya anemia pada pasien TB paru.

Isoniazid dan rifampisin adalah obat yang dapat menyebabkan anemia hemolitik dengan mekanisme kompleks imun, kompleks obat antibodi mengikat memban sel darah merah dan memicu aktivasi komplemen sehingga menimbulkan hemolisis sel darah merah atau penghancuran sel darah merah (Istiantoro YH \& Setiabudy R, 2012). Parameter pemeriksaan anemia yaitu meliputi hitung sel darah merah, kadar hemoglobin dan nilai hematokrit (Bakta IM, 2006). Oleh karena itu semakin lama pasien TB paru mengkonsumsi
OAT semakin menurun hitung sel darah merah, kadar hemoglobin dan nilai hematokrit.

Pada pasien TB paru yang sudah mengkonsumsi OAT selama 2 bulan rata-rata hitung sel darah merah $4,3910^{6} / \mathrm{uL}$, rata-rata kadar hemoglobin $12,73 \mathrm{~g} / \mathrm{dL}$ dan rata-rata nilai hematokrit 38,24\%. Dari hasil rata-rata pemeriksaan hitung sel darah merah, kadar hemoglobin dan nilai hematokrit tersebut bisa dikatakan pasien TB paru pada bulan ke 2 mengalami anemia.

Hasil penelitian Farazi dkk (2014) sebanyak $14,7 \%$ pasien terapi OAT mengalami gangguan hematologi akibat dari efek samping OAT. Hal serupa juga terjadi pada hasil penelitian Kassa dkk (2016) yang menunjukkan penurunan rata-rata kadar hemoglobin dari $12,7 \mathrm{~g} / \mathrm{dL}$ sebelum mengkonsumsi OAT menjadi $11,8 \mathrm{~g} / \mathrm{dL}$ setelah mengkonsumsi OAT, dan penurunan ratarata nilai hematokrit dari 38,5\% sebelum mengkonsumsi OAT menjadi 35,7 \% setelah mengkonsumsi OAT. Hal tersebut menunjukkan bahwa efek samping OAT bisa menyebabkan pasien TB paru menjadi anemia.

Pada hasil penelitian Farhanisa dkk (2015) kejadian efek samping OAT yang sering dikeluhkan oleh pasien diantaranya mual, lemas, muntah dan pusing. Mual merupakan efek samping yang langsung dirasakan oleh pasien setelah selesai meminum obat. Penelitian ini didukung oleh Caroll dkk (2012) yang melibatkan 655 responden, diperoleh hasil bahwa efek samping utama yang paling sering dirasakan adalah gangguan pencernaan (mual, muntah, diare dan nyeri perut). Hal ini juga dibuktikan oleh penelitian Sinha dkk (2013) bahwa efek samping yang paling banyak dialami adalah gastronintestinal $(53,52 \%)$. Begitu pun pada penelitian Kurniawati dkk (2012), bahwa efek samping yang umum terjadi adalah efek gastrointestinal (mual dan muntah). Hasil penelitian diatas menunjukkan bahwa salah satu efek samping dari OAT yang paling banyak dialami oleh pasien adalah mual, pusing dan gangguan pencernaan, efek samping tersebut kemungkinan dapat menyebabkan pasien mengalami penurunan nafsu makan sehingga akan mempengaruhi asupan gizi pada tubuh pasien tersebut. Menurut penelitian Lee SW dkk (2006) kekurangan gizi bisa menyebabkan penurunan pembentukan eritrosit. 
Asupan gizi yang baik sangat diperlukan bulan. pasien untuk mempercepat kesembuhan dan mencegah anemia karena efek samping dari OAT.

Penelitian ini pada bulan ke 6 rata-rata hitung sel darah merah $4,6110^{6} / \mathrm{uL}$, rata-rata kadar hemoglobin $13,28 \mathrm{~g} / \mathrm{dL}$ dan rata-rata nilai hematokrit 39,04 \%. Terjadi peningkatan sedikit dikarenakan frekuensi minum obat tidak sesering pada bulan pertama dan kedua, TB paru pasien sudah menjadi negatif serta dari hasil kuisioner gaya hidup responden yang baik seperti mengkonsumsi makanan yang bergizi, tidur yang cukup dan teratur.

Konsumsi OAT yang tidak sesering pada bulan ke 2, hal ini sesuai dengan hasil penelitian dari Sari ID dkk (2014) pada 2 bulan pertama tahap pengobatan pasien sering mengeluhkan rasa mual dan pusing dikarenakan salah satu efek samping obat tersebut dan konsumsi yang setiap hari. Rasa mual dan pusing tersebut akan mempengaruhi pola makan pasien yang menyebabkan pasien menjadi kurang nafsu makan kemudian pada bulan ke 5 dan ke 6 rasa mual dan pusing tersebut berkurang karena konsumsi OAT tidak setiap hari lagi sehingga nafsu makan pasien tidak terganggu.

Efek samping mengkonsumsi OAT bisa menyebabkan anemia, seperti pada hasil penelitian Farazi dkk (2014) dan Kassa dkk (2016). Penelitian ini pada bulan ke 6 terjadi peningkatan sedikit hitung sel darah merah, kadar hemoglobin dan nilai hematokrit. Hal ini dikarenakan frekuensi minum obat tidak sesering pada bulan pertama dan kedua, TB paru pasien sudah menjadi negatif serta dari hasil kuisioner gaya hidup responden yang baik seperti mengkonsumsi makanan yang bergizi, tidur yang cukup dan teratur.

\section{KESIMPULAN}

Ada hubungan antara lama konsumsi obat anti tuberkulosis terhadap anemia pada pasien TB paru berdasarkan uji korelasi Spearman.

\section{SARAN}

Perlu dilakukan penelitian lebih lanjut mengenai hubungan lama konsumsi obat anti tuberkulosis pada pasien TB paru dengan parameter yang berbeda seperti jumlah trombosit dan kadar AST/ALT menggunakan sampel atau pasien yang sama dari 0 bulan sampai 6

\section{DAFTAR PUSTAKA}

Bakta I M. (2006). Hematologi klinik ringkas. Jakarta: EGC.

Caroll, M. W., \& et. all. (2012). Frequency of adverse reactions to first-and second-line anti-tuberculosis chemotherapy in a Korean Cohort. IntJTuberc Lung Dis, 16(7), 961-967.

Farazi A, Sofian M, Jabbariasl M, \& Keshavarz S. (2014). Adverse reactions to antituberculosis drugs in Iranian tuberculosis patients. Hindawi Publishing Corporation.

Farhanisa, Untari E K, \& Nansy E. (2015). Kejadian efek samping obat anti tuberkulosis (OAT) kategori I pada pasien tb paru di unit pengobatan penyakit paru -paru (UP4) provinsi Kalimantan Barat. Jmfarmasi, 3(1), 7-9.

Istiantoro YH, \& Setiabudy R. (2012). Farmakologi dan terapi (5th ed.). Jakarta: Fakultas Kedokteran Universitas Indonesia.

Kassa E, Enawgaw B, Gelaw A, \& Gelaw B. (2016). Effect of anti-tuberculosis drugs on hematological profiles of tuberculosis patients attending at University of Gondarn hospital, Northwest Ethiopia. BMC Hematology.

Kurniawati $F$, Sulaiman SAS, \& Gillani WS. (2012). Adverse drug reactions of patients anti -tuberculosis drugs among tuberculosis patients treated in chest clinic. International Journal of Pharmacy \& Life Sciences, 3(1), 1331-1338.

Lee, S., \& et. all. (2006). The prevalence and evolution of anemia associated with tuberculosis. J Korean Med, 21(6), 102832.

Sari I D, Yuniar Y, \& Syaripuddin M. (2014). Studi monitoring efek samping obat Anti tuberkulosis FDC kategori 1 di Provinsi Banten dan Provinsi Jawa Barat. Media Litbangkes, 24(1), 28-35.

Sinha K, Marak ITR, \& Singh WA. (2013). Adverse drug reactions in tuberculosis patients due to directly observed treatment strategy therapy: Experience at an outpatient clinic of a teaching hospital in the city of Imphal, Manipur, India. The Journal of Association of Chest Physicians, 1 (2), 50-53. 